\title{
Suppression of thymosin $\beta 10$ increases cell migration and metastasis of cholangiocarcinoma
}

\author{
Sirinapa Sribenja ${ }^{1,2}$, Kanlayanee Sawanyawisuth ${ }^{1}$, Ratthaphol Kraiklang ${ }^{1}$, Chaisiri Wongkham', \\ Kulthida Vaeteewoottacharn ${ }^{1}$, Sumalee Obchoei ${ }^{1}$, Qizhi Yao ${ }^{2}$, Sopit Wongkham ${ }^{1}$ and Changyi Chen ${ }^{2 *}$
}

\begin{abstract}
Background: Thymosin $\beta 10$ (Tß10) expression is associated with malignant phenotypes in many cancers. However, the role and mechanisms of T $\beta 10$ in liver fluke-associated cholangiocarcinoma (CCA) are not fully understood. In this study, we investigated the expression of T $\beta 10$ in CCA tumor tissues and cell lines as well as molecular mechanisms of Tß10 in tumor metastasis of CCA cell lines.

Methods: T $\beta 10$ expression was determined by real time RT-PCR or immunocytochemistry. T $\beta 10$ silence or overexpression in CCA cells was achieved using gene delivery techniques. Cell migration was assessed using modified Boyden chamber and wound healing assay. The effect of silencing T 10 on CCA tumor metastasis was determined in nude mice. Phosphorylation of ERK1/2 and the expression of EGR1, Snail and matrix metalloproteinases (MMPs) were studied.
\end{abstract}

Results: Ten pairs of CCA tissues (primary and metastatic tumors) and 5 CCA cell lines were studied. With real time RT-PCR and immunostaining analysis, T 310 was highly expressed in primary tumors of CCA; while it was relatively low in the metastatic tumors. Five CCA cell lines showed differential expression levels of T $\beta 10$. Silence of T $\beta 10$ significantly increased cell migration, invasion and wound healing of CCA cells in vitro; reversely, overexpression of T $\beta 10$ reduced cell migration compared with control cells $(P<0.05)$. In addition, silence of T $\beta 10$ in CCA cells increased liver metastasis in a nude mouse model of CCA implantation into the spleen. Furthermore, silence of T 10 activated ERK1/2 and increased the expression of Snail and MMPs in CCA cell lines. Ras-GTPase inhibitor, FPT inhibitor III, effectively blocked T 310 silence-associated ERK1/2 activation, Snail expression and cell migration.

Conclusions: Low expression of T 10 is associated with metastatic phenotype of CCA in vitro and in vivo, which may be mediated by the activation of Ras, ERK1/2 and upregulation of Snail and MMPs. This study suggests a new molecular pathway of CCA pathogenesis and a novel strategy to treat or prevent CCA metastasis.

Keywords: Thymosin $\beta 10$, Cholangiocarcinoma, Cell migration, Cancer metastasis, Snail, ERK1/2, MMPs

\section{Background}

Cholangiocarcinoma (CCA), the malignancy of bile duct epithelial cells, is a major cancer and a main health problem in the northeast of Thailand [1,2]. A global increase in CCA related mortality and incidence of CCA have been reported [3,4]. Several conditions associated with chronic inflammation have been identified as risk factors for CCA. Infection with the liver fluke (Opisthorchis viverrini) is the

\footnotetext{
* Correspondence: jchen@bcm.tmc.edu

${ }^{2}$ Molecular Surgeon Research Center, Division of Surgical Research, Michael E. DeBakey Department of Surgery, Baylor College of Medicine, Houston, TX, USA Full list of author information is available at the end of the article
}

major risk factor of CCA in Thailand and Southeast Asia [5]; whereas primary sclerosing cholangitis is the main risk factor in Western countries [6].

Since CCA is difficult to diagnose at an early stage, almost all patients with CCA present with advanced, incurable disease. Even in patients who have undergone complete surgical resection, the recurrence rate remains quite high and the 5-year survival rate is unfavorable $[7,8]$. CCA is a slow growing but highly metastatic cancer, which is the major cause of death in CCA patients. Currently, there are no effective chemotherapeutic drugs and sensitive tumor markers to diagnose or monitor the tumor progression; most of CCA patients present

\section{Biomed Central}


themselves with high metastasis to lymph nodes and blood vessels. Therefore, understanding the molecular mechanism underlying CCA metastasis will lead to development of new strategies for the diagnosis and the treatment of CCA.

We have established the serial analysis of gene expressions (SAGE) database of the primary and corresponding metastatic tumors from a Thai male patient with CCA, as well as high and low invasive CCA cell lines (http://cgap. nci.nih.gov/SAGE). The differential expression of genes in primary vs. metastatic tumors has been recently reported [9]. Thymosin $\beta 10$ (T $\beta 10$ ) (TMSB10; SAGE tag: GGGG AAATCG) was highly expressed in primary CCA tumors; while it was reduced dramatically in the metastatic tumors (6.5 fold decrease). Furthermore, immunohistochemical (IHC) staining showed that the intensity of T $\beta 10$ staining in the primary CCA tumor tissue was higher than that in the normal liver tissue. However, the impact of the suppression of T $\beta 10$ on the metastasis of CCA is not known.

$\mathrm{T} \beta 10$ is a member of the $\beta$-thymosin family, which is widely distributed in many tissues with proven biological activities as an actin sequestering protein involved in cell motility. There are at least $15 \beta$-thymosins discovered, of which $\mathrm{T} \beta 4$ and $\mathrm{T} \beta 10$ are the most commonly found in mammalian cells with $\mathrm{T} \beta 4$ being the major form (70 $80 \%)$. T $\beta 4$ and $\mathrm{T} \beta 10$ are mainly localized in cytoplasm, and have high affinity to G-actin (actin monomer); while the expression and functions of $\mathrm{T} \beta 4$ and $\mathrm{T} \beta 10$ are quite different [10-13]. T $\beta 10$ is differentially expressed in embryogenesis and neuronal development. Its expression is also increased in many inflammatory conditions and tumorigenesis including cell proliferation, anti-apoptosis and angiogenesis [14-16]. However, the functional association of $\mathrm{T} \beta 10$ with tumor metastasis is controversial. High levels of $\mathrm{T} \beta 10$ expression were found in the metastatic tumor of thyroid $[17,18]$ and cutaneous malignancy [19]; while the low level of $\mathrm{T} \beta 10$ expression was associated with metastatic cervical carcinoma [20] and CCA [9].

In this study, the expression of $\mathrm{T} \beta 10$ in the primary and metastatic CCA was determined. The functional role of T $\beta 10$ in CCA cell migration and metastasis was studied in CCA cell lines and a nude mouse model of CCA xenograft. Moreover, the possible signaling pathway of $\mathrm{T} \beta 10$ in tumor metastasis was explored.

\section{Methods}

\section{Patient tissues}

Primary and corresponding metastatic CCA tissues ( $\mathrm{n}=$ 10) were obtained from the specimen bank of the Liver Fluke and Cholangiocarcinoma Research Center. Specimens were collected from intrahepatic CCA patients who underwent surgery at Srinagarind hospital, Faculty of Medicine, Khon Kaen University. Informed consent was obtained from each subject before surgery, and the
Human Research Ethics Committee at the Khon Kaen University, Thailand approved the research protocol. The specimens were kept frozen in Trizol (Invitrogen, CA) at $80^{\circ} \mathrm{C}$ until use.

\section{Cell lines and cell culture}

CCA cell lines, KKU-M055, KKU-100, KKU-M156, KKUM213 and KKU-M214, were established from primary tumors of Thai patients with different histological types $[21,22]$. All cell lines were cultured in the DMEM medium supplemented with $10 \% \mathrm{w} / \mathrm{v}$ fetal bovine serum (FBS), 100 $\mathrm{U} / \mathrm{mL}$ penicillin and $100 \mu \mathrm{g} / \mathrm{mL}$ streptomycin at $37^{\circ} \mathrm{C}$ and $5 \% \mathrm{CO}_{2}$.

\section{Chemicals and reagents}

DMEM medium, fetal bovine serum (FBS), trypsin EDTA, Opti-MEM I medium and LipofectAmine ${ }^{\text {TM }} 2000$ transfection reagent were purchased from Invitrogen Life Technology (Grand Island, NY). Puromycin and mouse anti- $\beta$-actin antibody were purchased from Sigma Chemical Co (St Louis, MO). Rabbit anti-T $\beta 10$ antibody was purchased from Biodesign International (Cincinnati, OH). Goat anti-rabbit IgG (H\&L) antibody conjugated to horseradish peroxidase (HRP), goat anti-mouse IgG (H\&L) antibody conjugated to HRP and rabbit anti-SNAl1 were obtained from Cell Signaling Technology Laboratories, Inc (Danvers, MA). Rabbit anti-ERK1/2 antibody, mouse anti-pERK1/2 antibody, mouse anti-Histone $\mathrm{H} 1$ and rabbit anti-EGR1 antibodies were obtained from Santa Cruz Biotechnology (Dallas, TX). The chemiluminescence (ECL) Prime Western Blotting Detection Reagent kit was purchased from GE Healthcare (Piscataway, NJ). The Ambion RNAqueous4PCR kit and DNA removing kits were purchased from Ambion (Austin, TX). The iQ SYBR Green supermix and iScript cDNA synthesis kits were purchased from Bio-Rad (Hercules, CA). All other chemicals were from Sigma.

\section{RNA extraction}

Total RNA was extracted using Ambion RNAqueous4PCR kit following the manufacture's instruction. Briefly, cells were lysed using lysis buffer, transferred to a minicolumn and centrifuged at $10,000 \times g$ for $1 \mathrm{~min}$. The column was washed and eluted in $60 \mu \mathrm{L}$ of elution buffer. RNA solution was treated with DNAse I to remove any trace amounts of genomic DNA contamination. The frozen mouse tumor tissues were soaked overnight in RNAlaterICE buffer (Ambion) before RNA extraction.

\section{Real time RT-PCR}

T $\beta 10$ mRNA levels were determined using real time RTPCR. Briefly, mRNA was reverse-transcribed into cDNA using the iScript cDNA synthesis kit and real time RTPCR was performed using the iQ SYBR Green supermix kit (Bio-Rad, Hercules, CA). The PCR reaction of $100 \mathrm{nM}$ 
of each primer, $20 \mathrm{ng}$ cDNA templates and iQ SYBR Green supermix, ran for 40 cycles of $95^{\circ} \mathrm{C}$ for $20 \mathrm{sec}$ and $60^{\circ} \mathrm{C}$ for $1 \mathrm{~min}$. Each cDNA sample was run in duplicate. $\beta$-actin was used as an internal loading control. The mRNA levels of early growth response protein 1 (EGR1), Snail, MMP3, MMP7 and MMP9 were similarly determined. The relative mRNA level was presented as unit values of $2^{[\mathrm{Ct}(\beta \text {-actin)-Ct(T } \beta 10)]}$. The primers for human $\mathrm{T} \beta 10$ and $\beta$-actin were used as described in our previous publication [23].

\section{Immunocytochemistry}

Cells were seeded into a 24-well plate $\left(2 \times 10^{4}\right.$ cells/well) and incubated in $5 \% \mathrm{CO}_{2}$ at $37^{\circ} \mathrm{C}$ for $24 \mathrm{~h}$. Cells were fixed with $95 \%$ ethanol and washed twice in PBS, then exposed to $0.3 \%$ hydrogen peroxide in absolute methanol to quench endogenous peroxidase, and blocked with 5\% FBS in PBS for $1 \mathrm{~h}$. Cells were incubated with 1:500 rabbit anti-T $\beta 10$ antibody (Biodesign, Cincinnati, $\mathrm{OH}$ ) at $4^{\circ} \mathrm{C}$ overnight. To visualize antibody binding, cells were reacted with anti-rabbit IgG EnVision (Dako, Carpinteria, $\mathrm{CA}$ ) for $30 \mathrm{~min}$ and diaminobenzidine (DAB) for $5 \mathrm{~min}$. The reaction was stopped by washing with distilled water followed by Mayer's haematoxylin staining.

\section{Nuclear extraction}

Cells were collected and washed with PBS. Cells were lyzed in $1 \mathrm{~mL}$ hypotonic buffer $(10 \mathrm{mM}$ HEPES-KOH $\mathrm{pH}$ 7.9, $1.5 \mathrm{mM} \mathrm{MgCl}_{2}, 10 \mathrm{mM} \mathrm{KCl}, 0.1 \% \mathrm{NP}-40,0.5$ mM DTT and $1 \times$ Protease inhibitor cocktail) and incubated on ice for $15 \mathrm{~min}$. Nuclei fraction was collected by centrifugation at 14,000 rpm for $30 \mathrm{sec}$, lyzed with $80 \mu \mathrm{L}$ of nuclear lysis buffer (50 mM HEPES-KOH pH 7.9, $10 \%$ glycerol, $420 \mathrm{mM} \mathrm{KCl,} 5 \mathrm{mM} \mathrm{MgCl} 2,0.1 \mathrm{mM}$ DTT and $1 \times$ Protease inhibitor cocktail), and incubated on ice for $30 \mathrm{~min}$. Nuclear extracts were obtained by centrifugation at $14,000 \mathrm{rpm}$ for $10 \mathrm{~min}$.

\section{Western blot}

Cells were lysed with radioimmuno-precipitation assay buffer (Pierce Biotechnology) for $30 \mathrm{~min}$ on ice. Whole cell lysates were then collected after centrifugation at 12,000 rpm for $10 \mathrm{~min}$ at $4^{\circ} \mathrm{C}$. Whole cell and nuclear fraction lysate $(30 \mu \mathrm{g})$ were loaded for ERK1/2, phosphorylated ERK1/ 2, EGR1 and Snail detection, respectively. Protein bands were separated with $12 \%$ Tris-Glycine SDS polyacrylamide gel electrophoresis and then transblotted for $2 \mathrm{~h}$ at $4{ }^{\circ} \mathrm{C}$ onto Hybond-P PVDF membrane (GE Healthcare, Piscataway, $\mathrm{NJ})$. The membrane was probed with rabbit anti-ERK1/2 antibody $(1: 2,000)$, mouse anti-pERK antibody $(1: 1,000)$ and anti- $\beta$-actin antibody $(1: 10,000)$ at room temperature for 1 $\mathrm{h}$ or rabbit anti-EGR1 (1:1000), rabbit anti-Snail (1:1000) and mouse anti-Histone $\mathrm{H} 1(1: 1000)$ antibody at $4^{\circ} \mathrm{C}$ overnight. Then, the membrane was incubated in a HRP-linked secondary antibody $(1: 20,000)$ for $1 \mathrm{~h}$ at room temperature; the immunoreactive bands were visualized using the chemiluminescence Prime Western Blotting Detection Reagent kit.

\section{Transient silence of $\mathrm{T} \beta 10$ by siRNA}

KKU-M214 and KKU-100 CCA cells (with a high endogenous $\mathrm{T} \beta 10$ expression; $2 \times 10^{4}$ cells/well) were seeded into a 6-well plate for $24 \mathrm{~h}$ before transfection. The siRNA specific sequence for targeting human T $\beta 10$ (5'-GCGGA GUGAAAUUUCCUAA-3'), corresponding to nucleotides 199 to 217 in the human sequence, was obtained from Ambion (Austin, TX). The cells were transfected either with $50 \mathrm{pM}$ siT $\beta 10$ or a control scramble RNA. Transfections were carried out by using the LipofectAmine ${ }^{\mathrm{Tm}} 2000$ (Invitrogen, CA) according to the manufacturer's instructions. After siRNA transfection, the plates were incubated at $37^{\circ} \mathrm{C}$ for $24 \mathrm{~h}$ for further analysis and total RNA was isolated with Trizol (Invitrogen, CA) reagent and reverse transcription-PCR was done.

\section{Establishment of stable cell lines and single clone selection}

To establish stable silence cell lines, shRNA plasmids and full-length cDNA plasmids used in the present study were purchased from OriGene and GeneCopoeia, respectively. Stable cells expressing T $\beta 10$ shRNA were created in KKUM055 and KKU-M214 cells by stably transfecting with HuSH 29mer shRNA construct against T $\beta 10$ (sh-T $\beta 10)$ to elicit silencing by use of a retroviral delivery system (OriGene Rockville, MD), following manufacturer's instructions. These were compared to cell lines transfected with the shRNA pRS non-effective GFP plasmids (sh-vector) as a negative control. The sequence of the T $\beta 10$ shRNA used in this study is as follows: 5'-AGATGGACACGA GCCACAAGCTGCACTGT-3'. Briefly, Phoenix ${ }^{\mathrm{mm}}$ Ampho Cells (Origene, Rockville, MD) were transfected with either T $\beta 10$ shRNA plasmid or shRNA vector control plasmid. Viral supernatants were collected and transduced into the parental KKU-M055 and KKU-M214 cells. Stable cell lines expressing T $\beta 10$ shRNA (M055-sh-T $\beta 10$ and M214-sh-T $\beta 10)$ or negative control vector (M055-sh-vector and M214-sh-vector) were selected with the addition of $1 \mu \mathrm{g} / \mathrm{mL}$ puromycin into the medium.

To generate stable overexpression stable cell lines by the lentiviral delivery system, full-length $T \beta 10$ cDNA plasmid called pReceiver-T $\beta 10-L v 105$ overexpression construct (GeneCopoeia) or pReceiver-eGFP-Lv105 vector as a control was co-transfected into 293T cells with HIV packing plasmids (GeneCopoeia). Viral supernatants were collected, filtered and transduced to the target cells. Stable cell lines expressing T $\beta 10$ (M055-Lenti-T $\beta 10$ and M213-LentiT 310 ) or GFP control (M055-Lenti-GFP and M213-LentiGFP) were selected with adding $0.5 \mu \mathrm{g} / \mathrm{mL}$ of puromycin 
into the medium. All stable cell lines were cultured for at least 2 weeks before use in experiments. T $\beta 10$ expression was confirmed by real time RT-PCR analysis. Fluorescence images of cells were captured to observe GFP signal in GFP control cells.

For isolation of individual clones, the cells were grown in the complete culture medium and then digested into individual cells with $0.05 \%$ trypsin-EDTA and plated at a density of 500 cells per $100-\mathrm{mm}$ cell culture dish in the presence of $0.5 \mu \mathrm{g} / \mathrm{mL}$ puromycin. Growth of the cell colonies was monitored by light microscopy. When the individual colonies reached approximately $100-200$ cells, positions of the solitary colony were marked and single cell clones were isolated by sterile cloning cylinders. Selected 5-8 single cell clones were subjected to expansion culture until sufficient amounts of cells were obtained.

\section{In vitro migration}

Cell migration was determined using a modified Boyden chamber assay. Uncoated- and pre-coated Matrigel-inserts ( $8 \mu \mathrm{m}$ pore size Transwell $^{\circ}$, Corning Inc., NY) were used for migration and invasion assay, respectively. Cells $\left(1 \times 10^{5}\right)$ were seeded into the upper compartment of the chamber and $600 \mu \mathrm{L}$ DMEM supplemented with $10 \%$ w/v FBS were placed into the lower chamber. After incubation at $37^{\circ} \mathrm{C}$ for an appropriate time, cells in the upper chamber were fixed with $4 \% \mathrm{w} / \mathrm{v}$ paraformaldehyde for $15 \mathrm{~min}$ and stained with $0.5 \% \mathrm{w} / \mathrm{v}$ crystal violet in $25 \% \mathrm{v} / \mathrm{v}$ methanol. Cells in the upper surface of the filter were scraped off using a cotton swab and the number of migrated cells in the lower surface was counted under microscope. Mean values of nine lowpower fields (100× magnification) were determined. For stable cell lines, after cells migrated at $37^{\circ} \mathrm{C}$ for the specified time, the cells were incubated with Calcein-AM (Molecular Probes, Eugene, OR) for $1 \mathrm{~h}$ at $37^{\circ} \mathrm{C}$ before fixation. The fluorescence was read from the bottom at an excitation wavelength of $495 \mathrm{~nm}$ and emission wavelength of $520 \mathrm{~nm}$. Cells in the upper chamber were then removed, and cells that had migrated onto the lower surface of the membrane were quantified. The migration rate was presented as the ratio of the mean fluorescence reading after scraping of the cells divided by the reading before removal of the top cells. Assays were done in triplicate and two independent experiments were repeated. In stable cell lines which incubated for migration more than $24 \mathrm{~h}$, cells were pretreated with $12.5 \mathrm{ng} / \mathrm{mL}$ Mitomycin C (Sigma-Aldrich, St. Louis, MO) for $3 \mathrm{~h}$ before seeded on the upper chamber to inhibit cell proliferation.

\section{Monolayer cell wound healing}

The stable cells were seeded into 6-well plates $\left(1.5 \times 10^{6}\right.$ cells/well) and incubated in a humidified atmosphere of $5 \% \mathrm{CO}_{2}$ at $37^{\circ} \mathrm{C}$ for $24 \mathrm{~h}$. To inhibit cell proliferation, a potential confounding variable, all wound assay cells were pretreated with $5 \mu \mathrm{g} / \mathrm{mL}$ Mitomycin C for $3 \mathrm{~h}$ before the scrape line was made. Wounds were generated on the surface of confluent monolayers using a sterile pipette tip, followed by incubation with DMEM medium supplemented with 10\% FBS. Healing was observed at different time points along the scrape line and a representative field for each cell line was photographed. Assays were done in triplicate and two independent experiments were repeated.

\section{Nude mouse model}

The following animal work was approved by the Office for Protection from Research Risks and Animal Welfare Act guidelines under an animal protocol approved by the Baylor College of Medicine Institutional Animal Care and Use Committee. Subconfluent and stable M214-sh-VectorGFP and M214-sh-T $\beta 10-G F P$ cells were harvested and resuspended in serum-free DMEM. For intrasplenic injection, mice were anesthetized with $2.5 \%$ avertin, and a 0.5 to $1-\mathrm{cm}$ incision was made in the left subcostal region. The spleen was exteriorized and the tumor cells $\left(2 \times 10^{6}\right.$ cells $)$ in a volume of $50 \mu \mathrm{L}$ were injected into the tail of spleen of 5 to 6-week-old male nude mice (NCI Charles River); four animals per group were used. The peritoneum and skin were closed with a 4.0 surgical suture. Mouse body weight was measured weekly. After 20 days of tumor implantation, all mice were euthanized by an overdose of $2.5 \%$ avertin and evaluated macroscopically for the presence of primary tumors in the spleen and the metastases in the liver, lung and abdominal cavity. To observe the gross nodule of liver metastasis, the whole livers were imaged under a fiber optic illumination LT-9900 Illumatool Bright Light System (Lightools Research, Encinitas, CA), and imaging was carried out at $470 \mathrm{~nm}$ with LT-9470FX $470 \mathrm{~nm}$ in Lightools Filter Cup (Lightools Research, Encinitas, CA). The total number of green fluorescent protein (GFP)-positive nodules in the surface of all lobes of liver was quantified. Next, the primary tumor site (spleen) and other organs (liver and lungs) were harvested; the whole organ of each specimen was embedded in Tissue-Tek ${ }^{\circ}$ OCT compound (Sakura Finetek Inc., Torrance, CA) and snap-frozen in liquid nitrogen before storage in $-80^{\circ} \mathrm{C}$ for further histological studies. For the micrometastasis study, liver dissections were sampled from the caudate and left lobe of each mouse. 14$\mu \mathrm{m}$ frozen sections were cut in a cryostat by following cryostat manufacturer's recommendation; then, the slides were fixed in $4 \%$ paraformaldehyde for $10 \mathrm{~min}$ at room temperature. All were visualized under an inverted fluorescent microscope using a $10 \times$ objective to verify the green signal of GFP. Six fields of GFP indicated areas of each liver section were taken and the number of micrometastasis was quantified. Tumors inside the abdominal cavity were stored in RNAlater solution (Ambion, Austin, TX) for real time RT-PCR analysis. 


\section{Statistical analysis}

Experimental data were analyzed using SPSS 13.0 Windows Evaluation software (SPSS Inc., Chicago, IL). All quantitative data were expressed as mean or percentage \pm SD. Two-tailed Student's $t$-test was used for comparison between two groups. Statistical significance was established at $P<0.05$.

\section{Results}

$\mathrm{T} \beta 10$ expression is decreased in the metastatic tumor of liver fluke-induced cholangiocarcinoma

Our SAGE data indicates that $\mathrm{T} \beta 10$ may play a role in CCA metastasis [9]. In this study, we determined the expression of $\mathrm{T} \beta 10$ in 10 pairs of CCA surgical specimens (primary and metastatic tumor) and 5 CCA cell lines previously isolated from the CCA tissues [21,22]. High expression of $\mathrm{T} \beta 10$ was found in the primary CCA tumor; while significantly low expression of $\mathrm{T} \beta 10$ was observed in the metastatic tumor by real time RT-PCR analysis and immunohistochemistry staining (Figure 1A, 1B). We also observed different endogenous T $\beta 10$ levels among 5 CCA cell lines (Figure 1C, 1D). Three CCA cell lines (KKUM055, KKU-M156 and KKU-M213) had a relatively low expression of T $\beta 10$; while other two cell lines (KKU-M214 and KKU-100) had a relatively high expression of T $\beta 10$.
These expression data provide a strong rationale for the functional analysis of $\mathrm{T} \beta 10$ in CCA.

\section{Silence of $\mathrm{T} \beta 10$ promotes cell migration and monolayer wound healing in liver fluke-induced cholangiocarcinoma cells}

To study the potential function of $\mathrm{T} \beta 10$ in CCA, we determined the effect of $\mathrm{T} \beta 10$ silence on cell migration in a KKU-M214 cell line, which showed a high expression of T $\beta 10$. KKU-M214 cells were transfected with $50 \mathrm{pM}$ of T $\beta 10$ siRNA (Ambion); and this reduced T $\beta 10$ mRNA levels by $50 \%$ at different time points $(48,72$ and $96 \mathrm{~h}$ ) and $\mathrm{T} \beta 10$ protein levels dramatically by immunocytochemistry analysis (Figure 2A). We performed migration and invasion assays by using a modified Boyden chamber method, and found that silence of T $\beta 10$ significantly enhanced cell migration and invasion of KKU-M214siT $\beta 10$ cells at $15 \mathrm{~h}$ and $18 \mathrm{~h}$, compared with those of KKU-M214-scramble RNA cells transfected with the scramble RNA (Figure 2B, $2 \mathrm{C} ;{ }^{*} \mathrm{P}<0.05 ; \mathrm{n}=3$ ).

To further confirm the role of $\mathrm{T} \beta 10$ silence in CCA migration, we established stable cell lines with $\mathrm{T} \beta 10$ silence in two CCA cell lines KKU-M214 and KKU-M055 by the retroviral vector delivery system and puromycin selection. Silencing of T $\beta 10$ in these cell lines was carefully confirmed by real time RT-PCR. The T $\beta 10$ mRNA

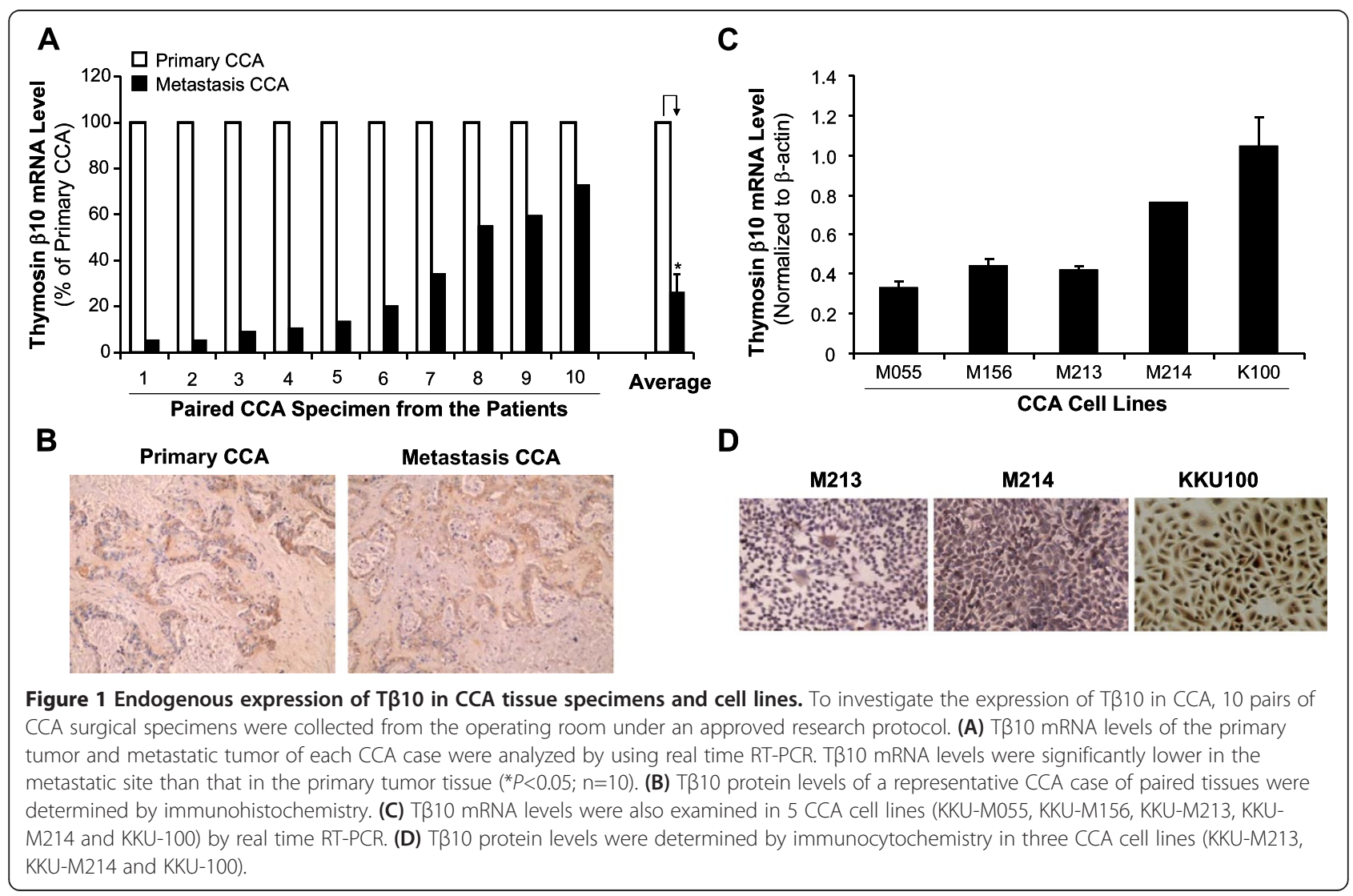




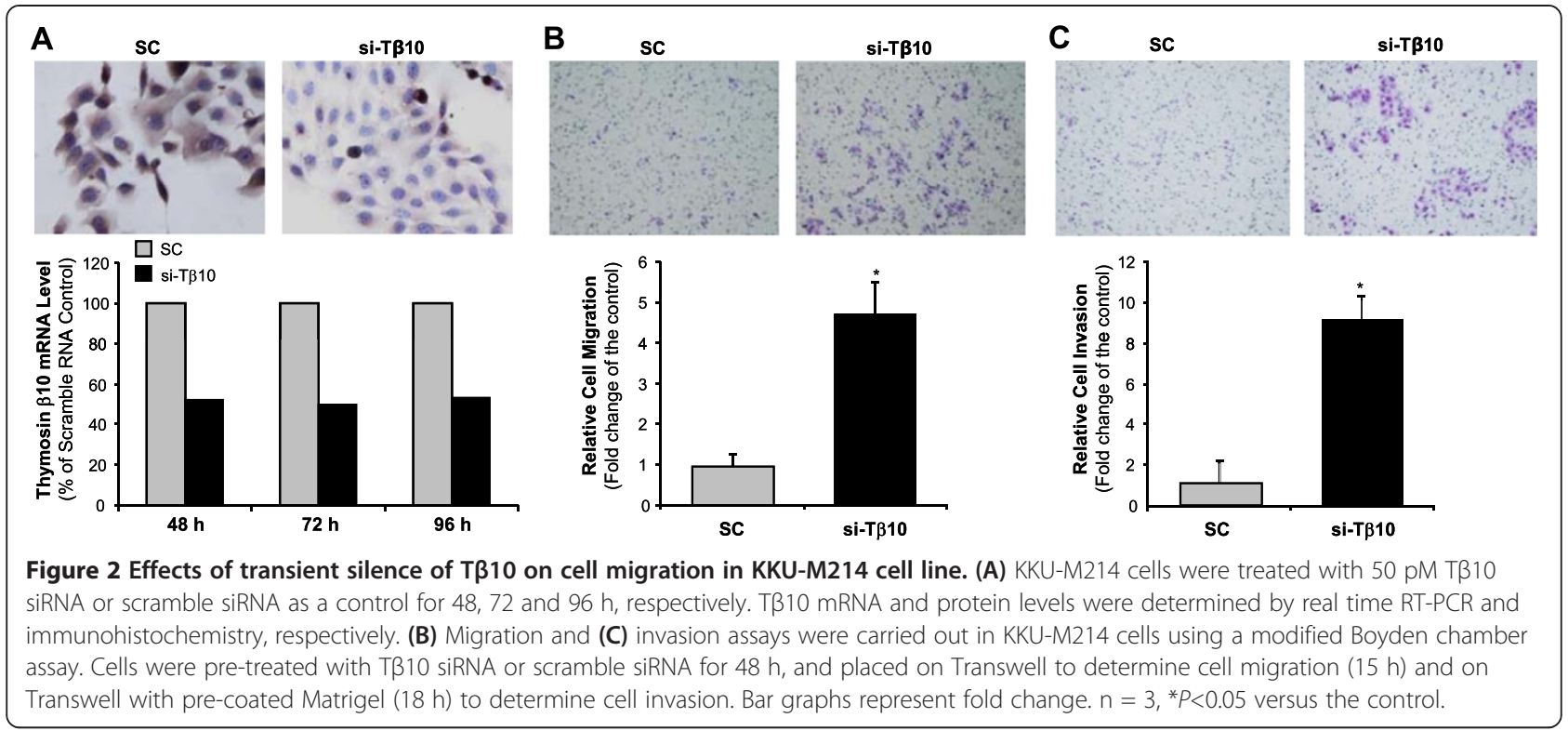

level of all single clones of M214-sh-T $\beta 10$ cells and scramble vector control cells as well as a representative of $\mathrm{T} \beta 10$ immunoreactivity are shown in Figure 3A. For the cell migration assay, silence of T $\beta 10$ in M214-sh$\mathrm{T} \beta 10$ cells was associated with 2.5 to 3 -fold increase in cell migration at $24 \mathrm{~h}$ and $48 \mathrm{~h}$, respectively, compared with that in M214-sh-vector cells (Figure $3 \mathrm{~B},{ }^{*} P<0.05 ; \mathrm{n}=3$ ). Similar results were also obtained in the monolayer wound healing assay; and low expression of $\mathrm{T} \beta 10$ resulted in an increase in cell migration of M214-sh-T $\beta 10$ cells
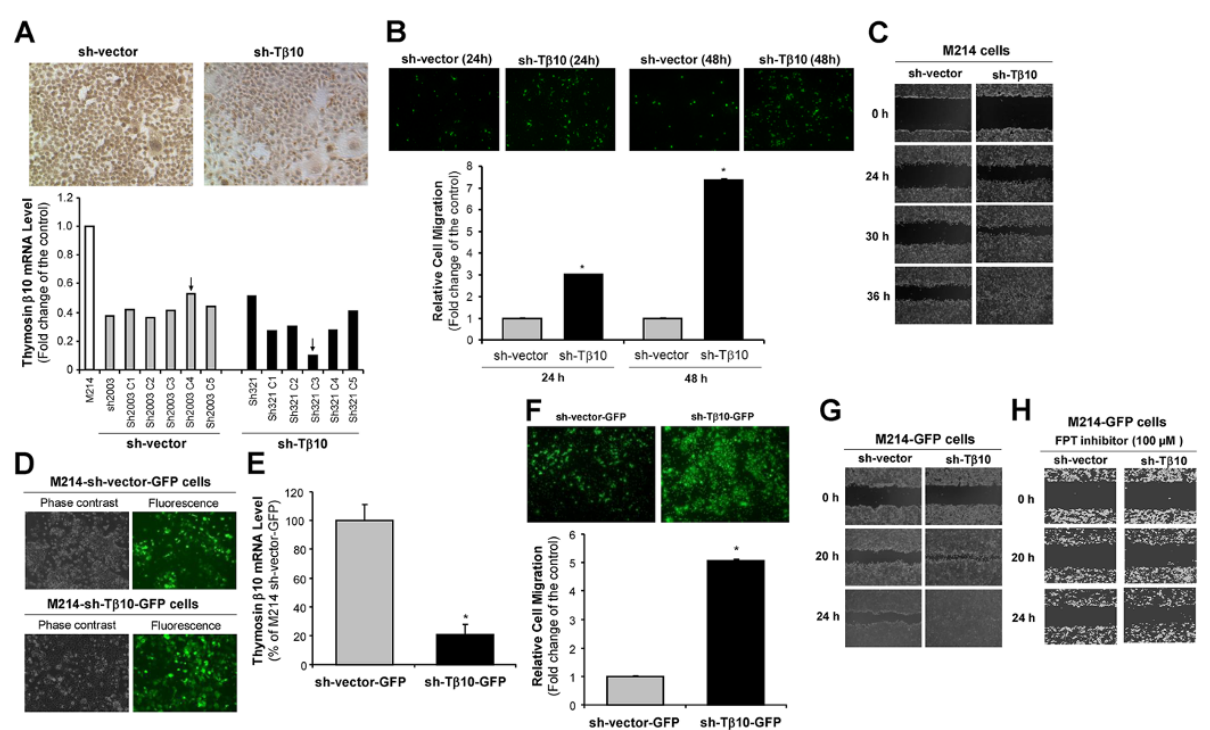

Figure 3 Effects of stable silence of T 310 on cell migration and monolayer wound healing in KKU-M214 cell line. Stable cell lines expressing

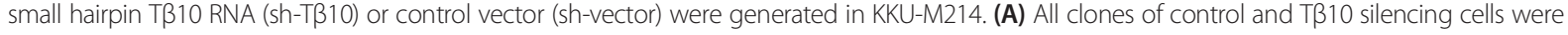
confirmed by real time RT-PCR. $\beta$-actin was used as an internal control. Arrows indicate selected clone for use in subsequent experiments; and insert pictures show immunocytochemistry results of selected clones. (B) Stable T $\beta 10$ silence led to enhanced KKU-M214 cell migration in vitro in 24 and $48 \mathrm{~h}$ incubation by the modified Boyden chamber assay. Bar graphs represent fold change. $n=3 ;{ }^{*} P<0.05$ versus the control. (C) Wound healing assay was carried out in M214-sh-vector and M214-sh-TB10 cells using DMEM medium supplemented with 10\% FBS. Representative images were taken from the same field at 0, 24, 30 and 36 h. (D) M214-sh-vector-GFP and M214-sh-Tß10-GFP cells were established, showing GFP signals. (E) The expression levels of TB10 in stable silence cells (M214-sh-Tß10-GFP cells and M214-sh-vector-GFP cells) were determined by real time RT-PCR. $n=3,{ }^{*} P<0.05$ versus the control. (F) Migration assay was carried out with M214-sh-vector-GFP and M214-sh-Tß10-GFP cells at $48 \mathrm{~h}$ incubation by the modified Boyden chamber assay. $n=3,{ }^{*} P<0.05$ versus the control. (G) Wound healing assay for M214-sh-vector-GFP and M214-sh-Tß10-GFP cells. Representative images were taken from the same field at 0, 20, and 24 h. (H) M214-sh-vector-GFP and M214-sh-Tß10-GFP cells were pre-treated with a Ras-GTPase inhibitor (FPT inhibitor III) for $2 \mathrm{~h}$. Wound healing assay was performed. Representative images were taken from the same field at 0, 20, and $24 \mathrm{~h}$. 
compared with that of M214-sh-vector cells in the presence of $5 \mu \mathrm{g} / \mathrm{mL}$ Mitomycin C, which inhibits cell proliferation (Figure $3 \mathrm{C}$ ).

In a parallel experiment, the M214-sh-vector and M214sh-T $\beta 10$ cells were established by double transfection with an eGFP expressing vector for use as a reporter signal for the imaging purpose in the animal study. To ensure that addition of eGFP did not alter T $\beta 10$ 's function in these cells, we performed the migration and wound healing assay in $\mathrm{T} \beta 10$ stable knockdown cells (M214-sh-T $\beta 10-G F P)$. Cells infected with Lentivirus contained-eGFP plasmid were selected in $1 \mu \mathrm{g} / \mathrm{mL}$ puromycin for 1 week before use in experiments. Phase contrast images of cells were captured on an inverted fluorescent microscope using a 10x objective to verify the green signal of GFP (Figure 3D). After transducing eGFP into the cells, we confirmed the expression of T $\beta 10$ in M214-sh-vector-GFP and M214-shT $110-G F P$ cells (Figure 3E). Then, we determined the effects of $\mathrm{T} \beta 10$ silence once again. Indeed, $\mathrm{T} \beta 10$ silence significantly increased the cell migration and monolayer wound healing in M214-sh-T $\beta 10-G F P$ cells compared with those in M214-sh-vector-GFP cells (Figure 3F, 3G). eGFP did not affect the function of $\mathrm{T} \beta 10$ silence in vitro.

The functional role of $\mathrm{T} \beta 10$ silence was confirmed in another CCA cell line KKU-M055, which has a relatively low expression of $\mathrm{T} \beta 10$ (about $50 \%$ of $\mathrm{T} \beta 10$ in $\mathrm{M} 214$ ). More CCA cell types studied in this project could demonstrate that the effect of $\mathrm{T} \beta 10$ silence on CCA migration is not cell type specific. KKU-M055 was chosen for both knockdown and overexpression of T $\beta 10$. Stable silence of T $\beta 10$ was successfully established in M055 (Figure 4A); silence of $\mathrm{T} \beta 10$ was associated with 3 -fold increased cell migration at $24 \mathrm{~h}$ in M055-sh-T $\beta 10$ cells, compared with those in sh-vector control cells (Figure $4 \mathrm{~B},{ }^{*} P<0.05 ; \mathrm{n}=3$ ). For the monolayer wound healing assay, one directional migration was substantially increased in M055-sh-T $\beta 10$ cells, compared with that in M055-sh-vector control cells (Figure 4C). These results demonstrate that $\mathrm{T} \beta 10$ negatively regulates CCA cell migration in vitro, which may play a critical role in the metastasis of CCA.

\section{Forced overexpression of $\mathrm{T} \beta 10$ decreases cell migration and monolayer wound healing in fluke-induced cholangiocarcinoma cells}

In order to further confirm the critical functions of T $\beta 10$ in cell migration, we determined the effects of T $\beta 10$ overexpression in two CCA cell lines KKU-M055 and KKUM213, which have a relatively low endogenous level of $\mathrm{T} \beta 10$. The stable cell lines were established by a lentiviral vector delivery system including pReceiver-T $\beta 10-L v 105$

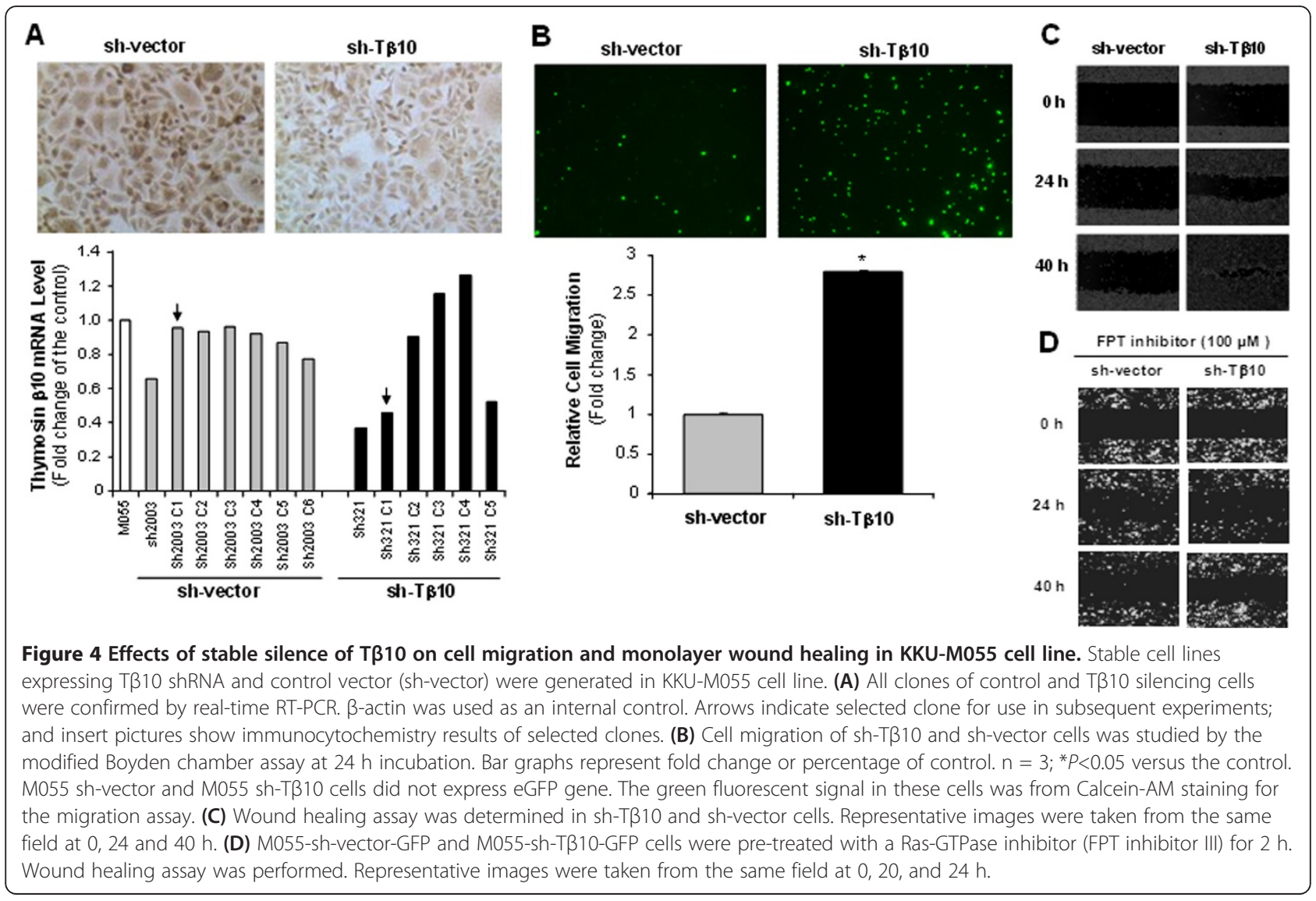


overexpression construct and pReceiver-eGFP-Lv105 control vector (GeneCopoeia). By real time RT-PCR analysis, overexpression of T $\beta 10$ in KKU-M055 (M055-Lenti-T $\beta 10)$ or KKU-M213 (M213-Lenti-Tß10) cell lines was confirmed, compared with the M055-Lenti-GFP or M213-Lenti-GFP control cells, respectively (Figure 5A, 5D). In Figure 5A, we chose the M055 control cell clone (GFP C6), which had a lowest expression of $\mathrm{T} \beta 10$, and the M055 stable overexpression clone (Tß10 C7), which had a highest expression of $\mathrm{T} \beta 10$, for further study because these clones may be more sensitive to determine the function of $\mathrm{T} \beta 10$ in CCA. T $\beta 10$ mRNA levels in M055-Lenti-T $\beta 10$ cells or M213-Lenti-T $\beta 10$ cells were increased by 2.7 -fold or 2.5 fold, respectively, compared with M055-Lenti-GFP cells or M213-Lenti-GFP cells. For the cell migration assay, cell migration of M055-Lenti-T $\beta 10$ cells or M213-Lenti-T $\beta 10$ cells was $80 \%$ or $87 \%$ lower than those of M055-Lenti-GFP cells or M213-Lenti-GFP cells at $36 \mathrm{~h}$, respectively (Figure 5B,

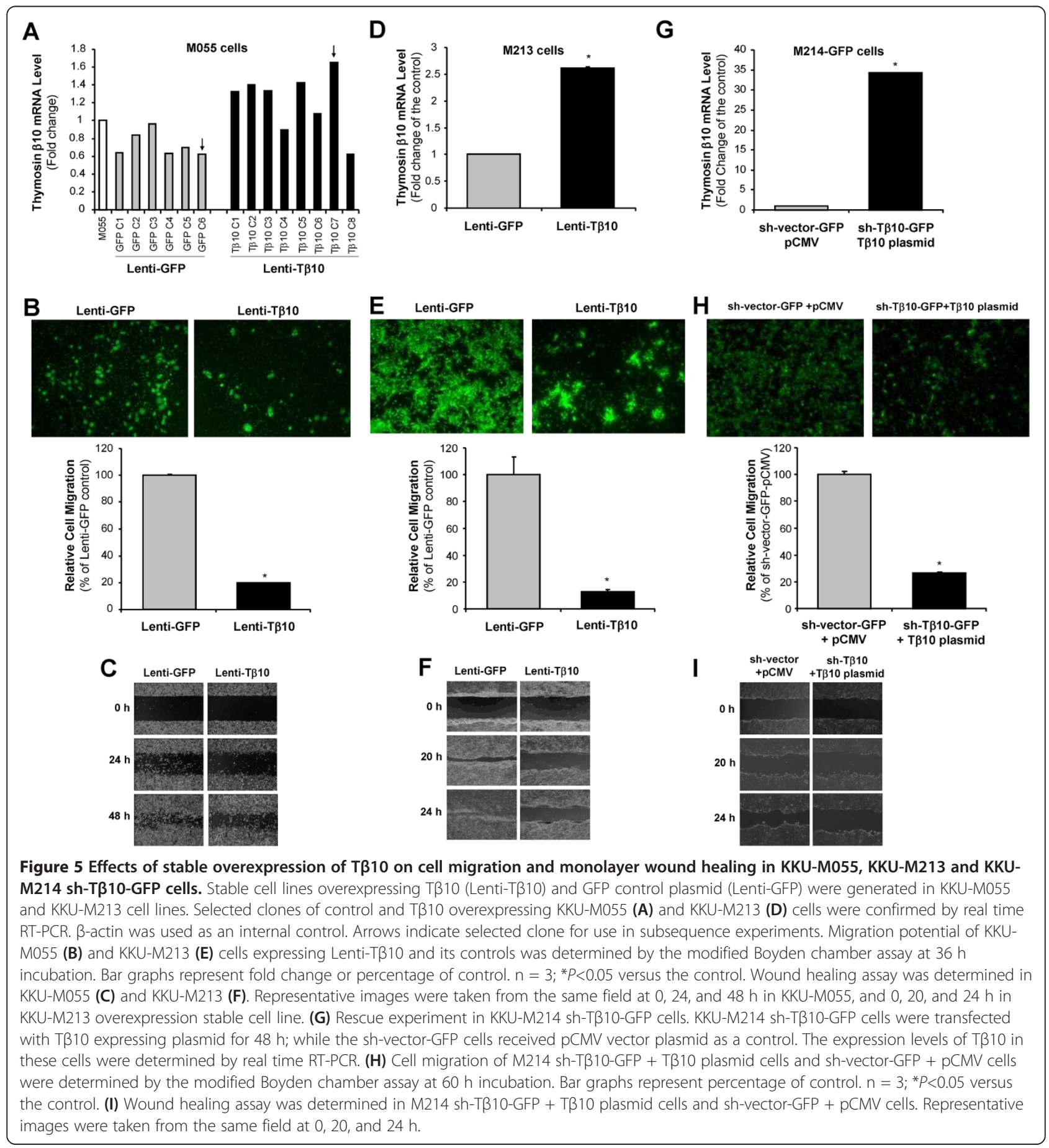


$5 \mathrm{E},{ }^{*} P<0.05 ; \mathrm{n}=3$ ). For the monolayer wound healing assay, $\mathrm{T} \beta 10$ forced overexpression also resulted in a lower cell migration rate in both M055-Lenti-T $\beta 10$ and M213Lenti-T $\beta 10$ cells, compared with that in their vector control cells (Figure 5C, 5F). These data demonstrate the suppression role of $\mathrm{T} \beta 10$ in cell migration of CCA.

To determine the specificity of the functional role of T 310 in CCA, we performed a rescue experiment in M214 sh-T $\beta 10-G F P$ cells, which have a reduced T $\beta 10$ level and increased cell migration. We hypothesized that reintroducing $\mathrm{T} \beta 10$ into this cell line would reverse its phenotype. We transiently transfected a pCMV6-XL5-T $\beta 10$ overexpression plasmid (OriGene) into the M214 sh-T $\beta 10-G F P$ cells and found that their T $\beta 10$ expression was 35-fold greater than those of pCMV6-XL5 empty vector control cells (Figure 5G). More importantly, forced T $\beta 10$ overexpression completely reversed the promotion of cell migration caused by shRNA silencing of $T \beta 10$ in both the modified Boyden chamber and the monolayer wound healing assays (Figure 5H, 5I).

\section{Stable silence of $\mathrm{T} \beta 10$ promotes tumor metastasis of} fluke-induced cholangiocarcinoma cells in nude mice As shown in Figure 3D, we established M214 sh-T $\beta 10$ and M214 sh-vector control cells with GFP expression, which can be used for the imaging of tumor metastasis in vivo. The effect of $\mathrm{T} \beta 10$ silence on the metastasis of CCA was analyzed in vivo using an immunodeficient nude mouse model. Twenty days after cells were injected orthotopically into the spleen of nude mice, the mice were sacrificed, and liver metastases were examined. The number of tumor metastasis nodules of the liver in the group of the mice injected with M214 sh-Tß10-GFP cells was greater than that in the mice injected with M214 shvector-GFP control cells (Figure 6A, 6B). In addition, metastasis nodules were observed in omental parenchyma in
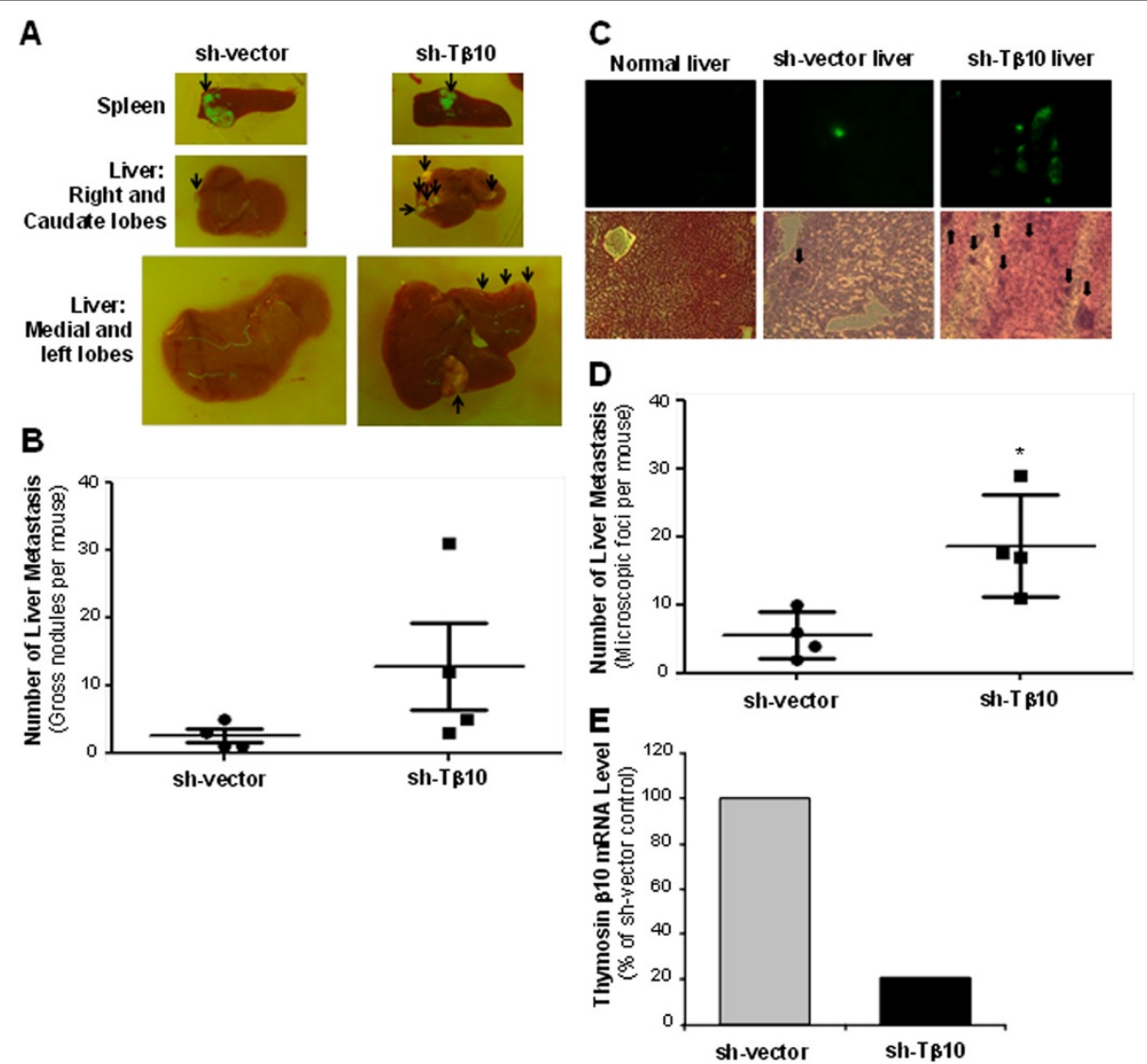

Figure 6 Effects of stable silence of Tß10 on tumor metastasis of KKU-M214 cell line in nude mice. (A) M214-sh-vector-GFP cells or M214sh-TB10-GFP cells were injected orthotopically into the spleen of nude mice for 3 weeks. Spleen (top), right and caudate lobes of liver (middle), medial and left lobes (bottom) were excised and GFP expressing tumors (black arrows) were examined using an UV illuminating system. (B) Graph showing the total number of GFP+ gross liver nodules in individual livers $( \pm S D ; n=4)$. (C) Representative pictures of liver micrometastasis. Frozen sections of the liver were cut from the caudate and left lobe of each mouse and visualized under a inverted fluorescent microscope using a 10X objective to verified the green signal of GFP; and 6 fields of GFP indicated area of each liver section were taken (top) and stained for H\&E (bottom). (D) The number of liver micrometastasis foci was quantified ( $\pm \mathrm{SD} ; \mathrm{n}=4,{ }^{*} P<0.05$ versus the control). (E) T $\beta 10$ silence persisted in the M214 sh-Tß10-GFP cell line-derived tumors compared with M214 sh-vector-GFP cell line-derived tumors by real-time RT-PCR. 
3 out of 4 mice injected with M214 sh-T $\beta 10-$ GFP cells; while 1 out of 4 mice injected with M214 sh-vector-GFP control cells had metastasis in the omental parenchyma. To observe liver micrometastasis, the liver tissues were sectioned and imaged for fluorescent GFP signal (CCA tumors), and the number of liver micrometastatic foci was counted under the fluorescent microscope. Micrometastatic lesions in the livers of mice injected with M214 sh$\mathrm{T} \beta 10-\mathrm{GFP}$ cells were significantly more than that of mice injected with M214 sh-vector-GFP control cells (Figure 6C, $\left.6 \mathrm{D},{ }^{*} P<0.05, \mathrm{n}=4\right)$. We confirmed that $\mathrm{T} \beta 10$ silence persisted in the nude mouse tumor derived from M214 shT $310-G F P$ cells by real-time RT-PCR (Figure 6E). These results demonstrate that stable silence of $\mathrm{T} \beta 10$ promotes the liver metastasis of CCA cells in the nude mouse model.

\section{Silence of $T \beta 10$ activates signaling pathways involved in tumor metastasis in fluke-induced cholangiocarcinoma cells}

It is well known that ERK1/2, EGR1 and the zinc-finger transcription factor, Snail, play critical roles in tumor metastasis in several cancer types [24-27]. However, it is not clear whether these signaling pathways are involved in the CCA. Cell lysates and nuclear extracts from KKUM055 and KKU-M214 cell lines with stable T $\beta 10$ silence or vector control cells were harvested and used for immunoblotting to detect the levels of total and phosphorylated ERK1/2, EGR1 and Snail. $\beta$-actin and histone H1 were used for loading controls. Stable silence of T $\beta 10$ in both KKU-M055 and KKU-M214 substantially activated ERK1/2 and increased Snail protein levels, but not EGR1 protein levels compared with that in vector control cells (Figure 7A, 7B). The mRNA levels of Snail and EGR1 were substantially increased in these CCA cells with T $\beta 10$ silence (Figure 7C, 7D). Thus, ERK1/2 and Snail pathways may be involved in the functional role of $\mathrm{T} \beta 10$ silenceinduced metastasis in CCA.

Since activated Ras can stimulate ERK1/2 in many cancer types [28], we hypothesized that the Ras-GTPase inhibitor may block activation of ERK1/2 and expression of EGR1 and Snail in T $\beta 10$-silenced CCA cell lines. We treated stable T $\beta 10$ knockdown cells (M055-sh-T $\beta 10$ and M214-sh-T $\beta 10)$ and their vector control cells (M055-shvector and M214-sh-vector) with a Ras-GTPase inhibitor, FPT inhibitor III, (100 $\mu \mathrm{M}$, Calbiochem, San Diego, CA) and performed Western blot analysis for phosphorylation of ERK1/2 and expression of EGR1 and Snail protein. FPT inhibitor III significantly inhibited activation of ERK/1/2 in both M055-sh-T $\beta 10$ and M214-sh-T $\beta 10$ cells (Figure 7A); and FPT inhibitor III also inhibited upregulation of Snail in both M055-sh-T $\beta 10$ and M214-sh-T $\beta 10$ cells (Figure 7B). In addition, pretreatment of FPT inhibitor III $(100 \mu \mathrm{M}$ for $2 \mathrm{~h}$ ) inhibited the wound healing in both M214-sh-T $\beta 10$ GPF cells (Figure 3H) and M055-sh-T $\beta 10$ cells (Figure 4D).
Matrix metalloproteinases (MMPs) also play a critical role in cancer migration, invasion and metastasis [29]. We determined the expression of MMP3, MMP7 and MMP9 in stable T $\beta 10$ knockdown cells (M055-sh-T $\beta 10$ and M214sh-T $\beta 10)$ and their vector control cells (M055-sh-vector and M214-sh-vector) by real time RT-PCR analysis. M055sh-T $\beta 10$ cells had a higher mRNA level of MMP3, MMP7 and MMP9 than the vector control cells had (Figure 7E). Similarly, M214-sh-T $\beta 10$ cells had a higher expression of MMP3 and MMP9 than M214-sh-vector cells had (Figure 7F). Thus, the loss of $\mathrm{T} \beta 10$ in CCA may increase the expression of MMPs, which contribute to the enhanced migration and invasion of CCA cells.

\section{Discussions}

In the current study, the functional role of $\mathrm{T} \beta 10$ in cell migration and tumor metastasis of CCA cell lines were investigated. Suppression of $\mathrm{T} \beta 10$ expression in CCA cell lines using siRNA-T $\beta 10$ or shRNA-T $\beta 10$ increases cell migration in vitro and enhances tumor metastasis in the nude mouse model. These results strongly suggest that suppression of $\mathrm{T} \beta 10$ in the primary CCA may increase its aggressiveness, possibly triggering some key signaling pathways for tumor metastasis.

There are numerous studies suggesting the critical roles for $\mathrm{T} \beta 10$ in tumorigenesis and progression of human cancers $[20,23,30-34]$. Expression of $\mathrm{T} \beta 10$ has been shown to confer cell migratory advantage in thyroid carcinoma $[17,18,35,36]$, and melanoma $[19,31,37]$; but disadvantage in endothelial cells [38] and ovarian cancer [24]. However, roles of T $\beta 10$ in cancer development such as cell growth and apoptosis still remain controversial among cancers $[15,16]$. At present, little is known about the expression and functions of $\mathrm{T} \beta 10$ in CCA. Using expressed sequence tags, $\mathrm{T} \beta 10$ was reported to be upregulated in intrahepatic CCA compared with normal liver tissues [39]. In this study, however, using real-time RT-PCR, we provide evidence, for the first time, that $\mathrm{T} \beta 10$ is upregulated in primary CCA; while it is significantly decreased in the metastatic CCA tumors. Functionally, reducing T $\beta 10$ expression by transiently and stably silencing technologies significantly enhanced the migration of CCA cell lines.

Recently, there have been many reports that describe the potential functional roles of T $\beta 10$ in human cancers; however, these functions are quite different among different types of cancers. $T \beta 10$ induces antiproliferative and proapoptotic effects in ovarian cancer; while in pancreatic cancer, $\mathrm{T} \beta 10$ stimulates secretion of proinflammatory cytokines interleukin (IL-7) and IL-8, which may promote pancreatic cancer pathogenesis and progression [23]. T $\beta 10$ inhibits tumor growth, angiogenesis, migration, and invasion of ovarian cancer in vitro and in vivo studies by disrupting actin polymerization and by inhibiting Ras action [24]. In our study, we demonstrate that $\mathrm{T} \beta 10$ 


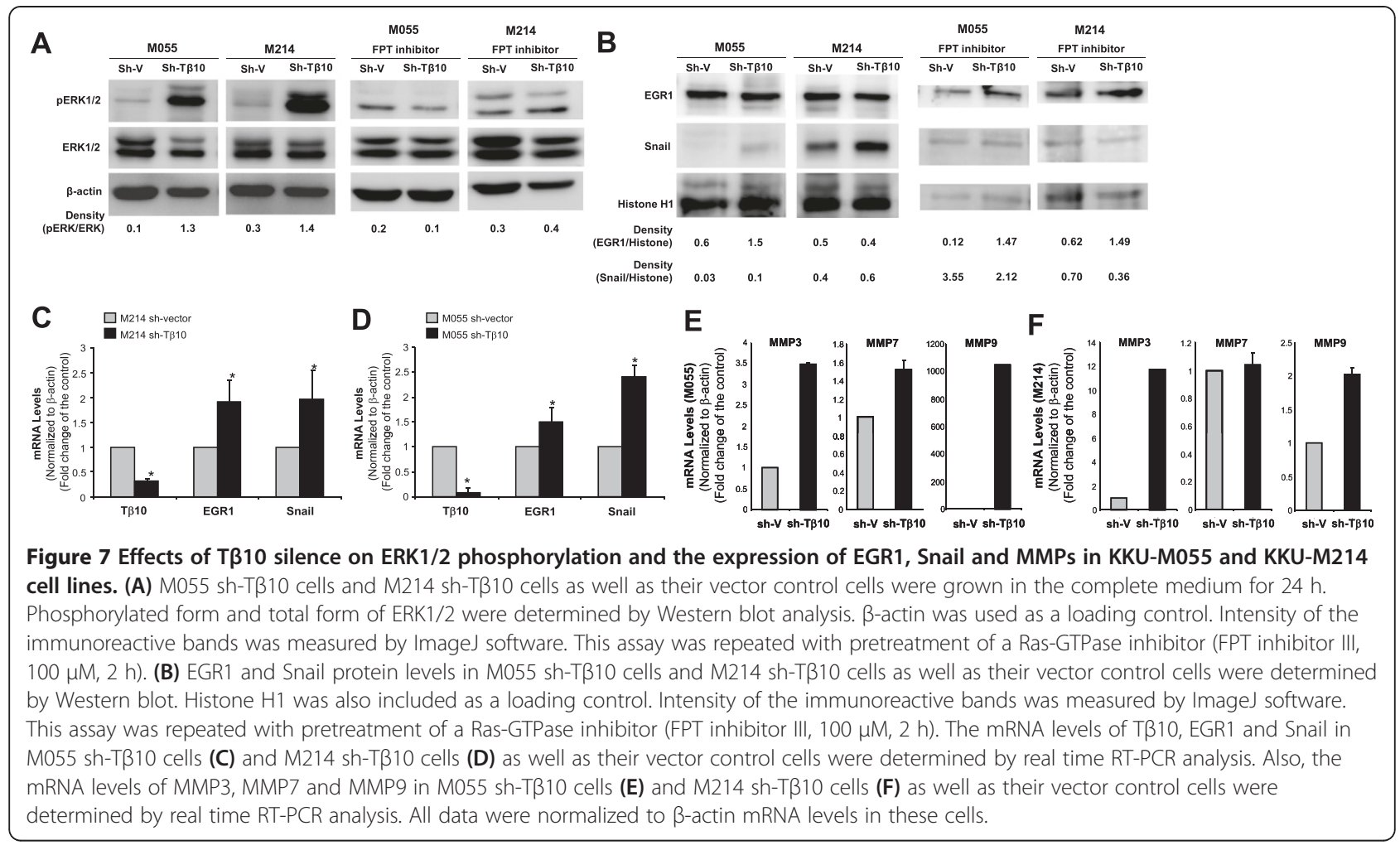

silence significantly promotes cell migration in CCA cell lines (KKU-M055 and KKU-M214 cells); while forced overexpression of T $\beta 10$ in CCA cell lines (KKU-M055, KKUM213) has an inhibitory effect on CCA migration. The function of T $\beta 10$ is specific because the effect of $T \beta 10$ silence can be reversed by overexpression of $\mathrm{T} \beta 10$ in CCA cell lines. T $\beta 10$ transiently silenced by siRNA oligonucleodie in KKU-M214 cells significantly increased both migration and invasion in M214 cells in vitro. However, the invasion was increased more than the migration in M214 cells with T $\beta 10$ silence. The reason for the difference of invasion and migration in the same cell type is not clear. It is possible that the migration and invasion have different molecular mechanisms. Invasion requires local proteolysis of the extracellular matrix (ECM), pseudopodial extension, and cell migration [40,41].

From technical aspects, sh-RNA retrovirus construct for $\mathrm{T} \beta 10$ (sh-T $\beta 10$ ) and empty control vector (sh2003) were used to infect both M214 and M055 CCA cells to establish stable silence cell lines by puromycin selection. Control vector nonspecifically reduced T $\beta 10$ mRNA in M214 clones, but did not affect $T \beta 10$ levels in M055. It is possible that different types of cells may contribute to this discrepancy. M214 was derived from a moderately differentiated CCA; while M055 was derived from a poorly differentiated CCA [21,22]. For the wound healing assay, control cells M055 Lenti-GFP had a lower wound healing rate compared with the control cells M213 Lenti-GFP although both cell types had a similar expression level of $\mathrm{T} \beta 10$. It is possible that different types of CCA cell lines have different mechanisms to control cell migration. Under the culture condition, M055 cells grow slower than M213 cells. In the rescue experiment, $\mathrm{T} \beta 10$-overexpressing plasmid was transiently transfected into the $\mathrm{T} \beta 10$ stable knockdown cells (M214 sh-T/10-GFP) and caused a 35-fold increase of T $\beta 10$ mRNA levels compared with that in vector control cells. It is possible that the overexpression of $\mathrm{T} \beta 10$ from the transiently transfected plasmid was strong and overcome sh-T $\beta 10$-mediated degradation of T $\beta 10$ in these rescue cells.

More importantly, we also demonstrate that silence of T $\beta 10$ in CCA cell lines enhanced tumor metastasis in the nude mouse model. These data may indicate clinical significance of the suppression of $\mathrm{T} \beta 10$ in metastatic CCA. Our results were consistent with previous studies in endothelial cells [38] and ovarian cancer [24,42,43].

However, it is not clear why metastatic CCA has a reduced expression of $\mathrm{T} \beta 10$. A current study has reported that approximately $16.7 \%$ of CCA have KRAS mutations [44], resulting in constitutively active Ras, which may contribute to the loss of $\mathrm{T} \beta 10$ expression. Other studies report that $\mathrm{T} \beta 10$ is differentially regulated by many factors such as retinoic acid and retinoids, growth factors and steroid hormones. For examples, vascular endothelial growth factor (VEGF), thyroid-stimulating hormones (TSH) upregulate T $\beta 10$ expression in a dose-dependent 
manner $[15,16]$. Moreover, chemotherapeutic drugs such as 5 -Fluorouracil (5-FU) has been shown to affect $\mathrm{T} \beta 10$ expression [45]. Thus, $\mathrm{T} \beta 10$ could be an important biomarker for 5-FU treatment.

Cell migration is a complex biological process involving highly orchestrated multistep process network of proteins and regulatory pathways. One of these regulatory pathways is the ERK1/2 MAPK pathway, which transduces extracellular signals into intracellular responses and is necessary for many cellular events [46,47]. To address regulatory pathways, which are associated with the functional role of $\mathrm{T} \beta 10$ silence in CCA, we determined the correlation between $\mathrm{T} \beta 10$ silence and activation of ERK1/2. Indeed, when $\mathrm{T} \beta 10$ was silenced in CCA cell lines, phosphorylation of ERK1/2 was substantially increased. It has been reported that ERK-mediated phosphorylation of FAK at $\mathrm{Ser}^{910}$ inhibits the interaction of FAK with paxillin, then regulate of the FAK-paxillin complex and it is possible that ERK-modulated disassembly of the FAK-paxillin complex is involved in focal adhesion disassembly [48]. This emphasizes that ERK is an important factor in the regulation of cell migration.

It is unknown how silence of T $\beta 10$ increases cell migration and metastasis of CCA. However, it is possible that suppression of $\mathrm{T} \beta 10$ increases the free form of G-actin, which is available for the dynamic actin polymerization especially in the cell front, thus enhances cell migration and tumor metastasis. Furthermore, $\mathrm{T} \beta 10$ is a key factor that interacts with Ras and inhibits Ras-dependent ERK1/2 signaling pathway [24]. It is recently reported that ERK $1 / 2$ activation mediates the expression of EGR1, which subsequently increases the invasive capability of ovarian cancer cells [49]. EGR1 also activates expression of Snail [50], a key inducer of epithelial-mesenchymal transition (EMT), which plays an important role in cancer metastasis [51-54]. In our current study, we demonstrate that $\mathrm{T} \beta 10$ silenceinduced cell migration and metastasis of CCA may also involve ERK12, EGR1 and Snail pathways. Silence of T $\beta 10$ substantially activated ERK1/2, and increased mRNA and protein levels of Snail and mRNA levels of EGR1 in CCA cell lines. However, silence of $\mathrm{T} \beta 10$ did not increase protein levels of EGR1. It is possible that Snail binds to the EGR1 promoter and represses EGR1 transcription, as well as its own promoter, thereby establishing a negative regulatory feedback loop $[50,55,56]$.

In addition, activation of ERK1/2 can be caused by KRAS mutation in many cancer types [28]. Our data also confirm this possibility in CCA. The Ras-GTPase inhibitor, FPT inhibitor III, effectively blocked the activation of ERK1/2 and the expression of Snail as well as the wound healing rate in T $\beta 10$-silenced CCA cell lines (M055-sh$\mathrm{T} \beta 10$ and M214-sh-T $\beta 10$ ).

Furthermore, high expression levels and activities of MMPs contribute to the invasiveness and metastasis potential in many types of cancers [29]. In the current study, we determined the relationship between silence of $\mathrm{T} \beta 10$ and expression of MMPs in CCA cell lines. Our data showed that stable T $\beta 10$ knockdown cells (M055-sh-T $\beta 10$ and M214-sh-T $\beta 10$ ) had a relatively higher expression of MMP3, MMP7 and MMP9 than their control cells. The loss of T $\beta 10$ in CCA may have a causal relationship with the increased expression of MMPs, which may enhance CCA metastasis.

Currently, functional roles and regulation mechanisms of Ras, ERK1/2, EGR1, Snail and MMPs in CCA metastasis are not fully understood. Further investigation into the whole picture of signaling mechanisms and protein interactions mediated by $\mathrm{T} \beta 10$ is warranted. It is not clear whether the current findings obtained from the research in the fluke-associated CCA are applicable to other types of CCA with different etiology. Now, there are no reports on the relationship between $\mathrm{T} \beta 10$ and other types of CCA. It could be a great opportunity for future investigation.

\section{Conclusions}

The present study demonstrates that $\mathrm{T} \beta 10$ expression is relatively high in the primary CCA tumor tissues; while it is dramatically reduced in the metastatic tumors. Overexpression of T $\beta 10$ reduces cell migration; whereas silence of T $\beta 10$ expression enhances CCA cell migration and invasion in vitro. Loss of $\mathrm{T} \beta 10$ expression accelerates tumor metastasis of CCA in the nude mouse model. Silence of T 10 mediates migration of CCA cells possibly through the activation of Ras, ERK1/2 and upregulation of Snail and MMPs. More studies in the molecular mechanisms of $\mathrm{T} \beta 10$ associated with cell migration and metastasis in CCA are warranted in order to develop new strategies to treat CCA.

\section{Competing interests}

The authors declare that they have no competing interests.

\section{Authors' contributions}

$\mathrm{SS}, \mathrm{KS}, \mathrm{RK}, \mathrm{CW}, \mathrm{KV}, \mathrm{SO}, \mathrm{QY}, \mathrm{SW}$ and CC designed research; SS and SO performed research; RK performed in-house PCR array; SS, KS, RK, CW, KV, SO, QY, SW and CC analyzed data; and SS, SW and CC wrote the paper. All authors read and approved the final manuscript.

\section{Acknowledgements}

This study was partially supported by the Michael E. DeBakey Department of Surgery and the Center for Globalization Pilot Project Grant from the Baylor College of Medicine, Houston, Texas, USA; the Higher Education Research Promotion and National Research University Project of Thailand, Office of the Higher Education Commission, through the Health cluster (SHeP-GMS); and Research strengthening grant from the Faculty of Medicine, Khon Kaen University 2550-2555; and the Royal Golden Jubilee PhD Program, Thailand Research Fund, Thailand (PHD/0059/2551) to Sribenja S and Wongkham S. Authors would like to thank Dr. Min Li, Dr. Christian Marin-Muller, Dr. Hao Wang, Dr. Lidong Zhang, and Dr. Jian-Ming Lu for their technique assistances.

\section{Author details}

${ }^{1}$ Department of Biochemistry, Liver Fluke and Cholangiocarcinoma Research Center, Faculty of Medicine, Khon Kaen University, Khon Kaen, Thailand. 
${ }^{2}$ Molecular Surgeon Research Center, Division of Surgical Research, Michael E. DeBakey Department of Surgery, Baylor College of Medicine, Houston, TX, USA.

Received: 15 May 2013 Accepted: 17 September 2013 Published: 23 September 2013

\section{References}

1. Shaib Y, El-Serag HB: The epidemiology of cholangiocarcinoma. Semin Liver Dis 2004, 24:115-125.

2. Sripa B, Kaewkes S, Sithithaworn P, Mairiang E, Laha T, Smout M, Pairojkul C, Bhudhisawasdi V, Tesana S, Thinkamrop B, et al: Liver fluke induces cholangiocarcinoma. PLoS Med 2007, 4:e201.

3. Khan SA, Taylor-Robinson SD, Toledano MB, Beck A, Elliott P, Thomas HC Changing international trends in mortality rates for liver, biliary and pancreatic tumours. J Hepatol 2002, 37:806-813.

4. Patel $\mathrm{T}$ : Worldwide trends in mortality from biliary tract malignancies. BMC Cancer 2002, 2:10.

5. Vatanasapt V, Uttaravichien T, Mairiang EO, Pairojkul C, Chartbanchachai W, Haswell-Elkins M: Cholangiocarcinoma in north-east Thailand. Lancet 1990, 335:116-117.

6. Burak K, Angulo P, Pasha TM, Egan K, Petz J, Lindor KD: Incidence and risk factors for cholangiocarcinoma in primary sclerosing cholangitis. Am J Gastroenterol 2004, 99:523-526.

7. Anderson CD, Pinson CW, Berlin J, Chari RS: Diagnosis and treatment of cholangiocarcinoma. Oncologist 2004, 9:43-57.

8. Kawarada Y, Yamagiwa K, Das BC: Analysis of the relationships between clinicopathologic factors and survival time in intrahepatic cholangiocarcinoma. Am J Surg 2002, 183:679-685.

9. Sawanyawisuth K, Wongkham C, Araki N, Zhao Q, Riggins GJ, Wongkham S: Serial analysis of gene expression reveals promising therapeutic targets for liver fluke-associated cholangiocarcinoma. Asian Pac J Cancer Prev 2012, 13:89-93.

10. Goldstein AL: History of the discovery of the thymosins. Ann N Y Acad SCi 2007, 1112:1-13.

11. Goldstein AL, Hannappel E, Sosne G, Kleinman HK: Thymosin beta(4): a multi-functional regenerative peptide. Basic properties and clinical applications. Expert Opin Biol Ther 2012, 12:37-51.

12. Hannappel E: \{beta\}-Thymosins. Ann N Y Acad Sci 2007, 1112:21-37.

13. Huff T, Muller CS, Otto AM, Netzker R, Hannappel E: Beta-Thymosins, small acidic peptides with multiple functions. Int J Biochem Cell Biol 2001, 33:205-220.

14. Chen $\mathrm{C}$, Li M, Yang H, Chai H, Fisher W, Yao Q: Roles of thymosins in cancers and other organ systems. World J Surg 2005, 29:264-270.

15. Sribenja S, Li M, Wongkham S, Wongkham C, Yao Q, Chen C: Advances in thymosin beta10 research: differential expression, molecular mechanisms, and clinical implications in cancer and other conditions. Cancer Invest 2009, 27:1016-1022.

16. Sribenja S, Wongkham S, Wongkham C, Yao Q, Chen C: Roles and mechanisms of beta-thymosins in cell migration and cancer metastasis: an update. Cancer Invest 2012, 31:103-110.

17. Califano D, Monaco C, Santelli G, Giuliano A, Veronese ML, Berlingieri MT, de Franciscis V, Berger N, Trapasso F, Santoro M, et al: Thymosin beta-10 gene overexpression correlated with the highly malignant neoplastic phenotype of transformed thyroid cells in vivo and in vitro. Cancer Res 1998, 58:823-828.

18. Takano T, Hasegawa Y, Miyauchi A, Matsuzuka F, Yoshida H, Kuma K, Amino N: Quantitative analysis of thymosin beta-10 messenger RNA in thyroid carcinomas. Jpn J Clin Oncol 2002, 32:229-232.

19. Weterman MA, van Muijen GN, Ruiter DJ, Bloemers HP: Thymosin beta-10 expression in melanoma cell lines and melanocytic lesions: a new progression marker for human cutaneous melanoma. Int J Cancer 1993, 53:278-284

20. Huang L, Zheng M, Zhou QM, Zhang MY, Jia WH, Yun JP, Wang HY: Identification of a gene-expression signature for predicting lymph node metastasis in patients with early stage cervical carcinoma. Cancer 2011, 117:3363-3373.

21. Sripa B, Leungwattanawanit S, Nitta T, Wongkham C, Bhudhisawasdi V, Puapairoj A, Sripa C, Miwa M: Establishment and characterization of an opisthorchiasis-associated cholangiocarcinoma cell line (KKU-100). World J Gastroenterol 2005, 11:3392-3397.

22. Obchoei S, Weakley SM, Wongkham S, Wongkham C, Sawanyawisuth $K$, Yao Q, Chen C: Cyclophilin A enhances cell proliferation and tumor growth of liver fluke-associated cholangiocarcinoma. Mol Cancer 2011 10:102.

23. Li M, Zhang Y, Zhai Q, Feurino LW, Fisher WE, Chen C, Yao Q: Thymosin beta-10 is aberrantly expressed in pancreatic cancer and induces JNK activation. Cancer Invest 2009, 27:251-256.

24. Lee SH, Son MJ, On SH, Rho SB, Park K, Kim YJ, Park MS, Lee JH: Thymosin \{beta\}(10) inhibits angiogenesis and tumor growth by interfering with Ras function. Cancer Res 2005, 65:137-148.

25. Gineitis D, Treisman R: Differential usage of signal transduction pathways defines two types of serum response factor target gene. J Biol Chem 2001, 276:24531-24539.

26. Guha M, O'Connell MA, Pawlinski R, Hollis A, McGovern P, Yan SF, Stern D, Mackman N: Lipopolysaccharide activation of the MEK-ERK1/2 pathway in human monocytic cells mediates tissue factor and tumor necrosis factor alpha expression by inducing Elk-1 phosphorylation and Egr-1 expression. Blood 2001, 98:1429-1439.

27. Shin SY, Lee JH, Min B, Lee YH: The translation inhibitor anisomycin induces Elk-1-mediated transcriptional activation of egr-1 through multiple mitogen-activated protein kinase pathways. Exp Mol Med 2006, 38:677-685.

28. Cagnol S, Rivard N: Oncogenic KRAS and BRAF activation of the MEK/ERK signaling pathway promotes expression of dual-specificity phosphatase 4 (DUSP4/MKP2) resulting in nuclear ERK1/2 inhibition. Oncogene 2013, 32:564-576.

29. Deryugina El, Quigley JP: Matrix metalloproteinases and tumor metastasis. Cancer Metastasis Rev 2006, 25:9-34.

30. Gu Y, Wang C, Wang Y, Qiu X, Wang E: Expression of thymosin beta10 and its role in non-small cell lung cancer. Hum Pathol 2009, 40:117-124.

31. Liu CR, Ma CS, Ning JY, You JF, Liao SL, Zheng J: Differential thymosin beta 10 expression levels and actin filament organization in tumor cell lines with different metastatic potential. Chin Med J (Engl) 2004, 117:213-218.

32. Santelli G, Califano D, Chiappetta G, Vento MT, Bartoli PC, Zullo F, Trapasso F, Viglietto G, Fusco A: Thymosin beta-10 gene overexpression is a general event in human carcinogenesis. Am J Pathol 1999, 155:799-804

33. van Groningen JJ, Cornelissen IM, van Muijen GN, Bloemers HP, Swart GW: Simultaneous suppression of progression marker genes in the highly malignant human melanoma cell line BLM after transfection with the adenovirus-5 E1A gene. Biochem Biophys Res Commun 1996, 225:808-816.

34. Verghese-Nikolakaki S, Apostolikas N, Livaniou E, Ithakissios DS, Evangelatos GP: Preliminary findings on the expression of thymosin beta-10 in human breast cancer. Br J Cancer 1996, 74:1441-1444.

35. Chiappetta G, Pentimalli F, Monaco M, Fedele M, Pasquinelli R, Pierantoni GM, Ribecco MT, Santelli G, Califano D, Pezzullo L, Fusco A: Thymosin beta10 gene expression as a possible tool in diagnosis of thyroid neoplasias. Oncol Rep 2004, 12:239-243.

36. Feher LZ, Pocsay G, Krenacs L, Zvara A, Bagdi E, Pocsay R, Lukacs G, Gyory F, Gazdag A, Tarko E, Puskas LG: Amplification of thymosin beta 10 and AKAP13 genes in metastatic and aggressive papillary thyroid carcinomas. Pathol Oncol Res 2012, 18:449-458.

37. Hardesty WM, Kelley MC, Mi D, Low RL, Caprioli RM: Protein signatures for survival and recurrence in metastatic melanoma. J Proteomics 2011, 74:1002-1014.

38. Mu H, Ohashi R, Yang H, Wang X, Li M, Lin P, Yao Q, Chen C: Thymosin beta10 inhibits cell migration and capillary-like tube formation of human coronary artery endothelial cells. Cell Motil Cytoskeleton 2006, 63:222-230.

39. Wang AG, Yoon SY, Oh JH, Jeon YJ, Kim M, Kim JM, Byun SS, Yang JO, Kim JH, Kim DG, et al: Identification of intrahepatic cholangiocarcinoma related genes by comparison with normal liver tissues using expressed sequence tags. Biochem Biophys Res Commun 2006, 345:1022-1032.

40. Bravo-Cordero JJ, Hodgson L, Condeelis J: Directed cell invasion and migration during metastasis. Curr Opin Cell Biol 2012, 24:277-283.

41. Woodhouse EC, Chuaqui RF, Liotta LA: General mechanisms of metastaisis. Cancer Supp/ 1997, 80:1529-2537.

42. Kim YC, Kim BG, Lee JH: Thymosin beta(10) expression driven by the human TERT promoter induces ovarian cancer-specific apoptosis through ROS production. PLoS One 2012, 7:e35399.

43. Lee SH, Zhang W, Choi JJ, Cho YS, Oh SH, Kim JW, Hu L, Xu J, Liu J, Lee JH: Overexpression of the thymosin beta-10 gene in human ovarian cancer 
cells disrupts F-actin stress fiber and leads to apoptosis. Oncogene 2001, 20:6700-6706.

44. Ong CK, Subimerb C, Pairojkul C, Wongkham S, Cutcutache I, Yu W, McPherson JR, Allen GE, Ng CC, Wong BH, et al: Exome sequencing of liver fluke-associated cholangiocarcinoma. Nat Genet 2012, 44:690-693.

45. Longley DB, Harkin DP, Johnston PG: 5-fluorouracil: mechanisms of action and clinical strategies. Nat Rev Cancer 2003, 3:330-338.

46. Huang $C$, Jacobson $\mathrm{K}$, Schaller MD: MAP kinases and cell migration. J Cell Sci 2004, 117:4619-4628.

47. Reddy KB, Nabha SM, Atanaskova N: Role of MAP kinase in tumor progression and invasion. Cancer Metastasis Rev 2003, 22:395-403.

48. Hunger-Glaser I, Salazar EP, Sinnett-Smith J, Rozengurt E: Bombesin, lysophosphatidic acid, and epidermal growth factor rapidly stimulate focal adhesion kinase phosphorylation at Ser-910: requirement for ERK activation. J Biol Chem 2003, 278:22631-22643.

49. Cheng JC, Chang HM, Leung PC: Egr-1 mediates epidermal growth factorinduced downregulation of E-cadherin expression via Slug in human ovarian cancer cells. Oncogene 2013, 32:1041-1049.

50. Grotegut S, von Schweinitz D, Christofori G, Lehembre F: Hepatocyte growth factor induces cell scattering through MAPK/Egr-1-mediated upregulation of Snail. EMBO J 2006, 25:3534-3545.

51. Mikami S, Katsube K, Oya M, Ishida M, Kosaka T, Mizuno R, Mukai M, Okada Y. Expression of Snail and Slug in renal cell carcinoma: E-cadherin repressor Snail is associated with cancer invasion and prognosis. Lab Invest 2011, 91:1443-1458.

52. Merikallio H, Turpeenniemi-Hujanen T, Pääkkö P, Mäkitaro R, Riitta K, Salo S, Salo T, Harju T, Soini Y: Snail promotes an invasive phenotype in lung carcinoma. Respir Res 2012, 13:104.

53. Jin H, Yu Y, Zhang T, Zhou X, Zhou J, Jia L, Wu Y, Zhou BP, Feng Y: Snail is critical for tumor growth and metastasis of ovarian carcinoma. Int J Cancer 2010, 126:2102-2111.

54. Shin NR, Jeong EH, Choi Cl, Moon HJ, Kwon CH, Chu IS, Kim GH, Jeon TY, $\mathrm{Kim} \mathrm{DH}$, Lee JH, Park Do Y: Overexpression of Snail is associated with lymph node metastasis and poor prognosis in patients with gastric cancer. BMC Cancer 2012, 12:521.

55. de Herreros AG, Peiro S, Nassour M, Savagner P: Snail family regulation and epithelial mesenchymal transitions in breast cancer progression. J Mammary Gland Biol Neoplasia 2010, 15:135-147.

56. Peiro S, Escriva M, Puig I, Barbera MJ, Dave N, Herranz N, Larriba MJ, Takkunen M, Franci C, Munoz A, et al: Snail1 transcriptional repressor binds to its own promoter and controls its expression. Nucleic Acids Res 2006, 34:2077-2084

doi:10.1186/1471-2407-13-430

Cite this article as: Sribenja et al:: Suppression of thymosin $\beta 10$ increases cell migration and metastasis of cholangiocarcinoma. BMC Cancer 2013 13:430.

\section{Submit your next manuscript to BioMed Central and take full advantage of:}

- Convenient online submission

- Thorough peer review

- No space constraints or color figure charges

- Immediate publication on acceptance

- Inclusion in PubMed, CAS, Scopus and Google Scholar

- Research which is freely available for redistribution 